\title{
CIRCULATING FIBROSIS MARKERS, EOSINOPHIL CATIONIC PROTEIN AND EOSINOPHIL PROTEIN X IN PATIENTS WITH WUCHERERIA BANCROFTI INFECTION: ASSOCIATION WITH CLINICAL STATUS
}

\author{
ESTERRE P.*, PLICHART C.*, HUIN-BLONDEY M.O.**, NGUYEN L.N.**, HARTMANN D.***, GUERRET S.**, \\ REIMERT C.M.***** \& RICARD-BLUM S.*****
}

\section{Summary:}

We measured the concentrations of several circulating fibrosis markers (type I collagen I, type III procollagen, hyaluronan) and eosinophil granule proteins (ECP and EPX) in lymphatic filariasis patients to investigate their relationship with clinical, parasitological and immunological data. This study was conducted in Polynesian patients with various stages of the disease lacute lymphangitis, chyluria, hydrocoele, elephantiasis), a closely related microbial lymphangitis and endemic controls. We observed modifications of the different markers in this pathology. Serum type I collagen and PIIINP were decreased. Serum hyaluronan, linked to perilymphatic granulomatous inflammation, was significantly increased in acute lymphangitis and elephantiasis patients. Serum ECP was also increased, at the limit of significance in our sample, in elephantiasis patients. These two last markers, already validated in another helminth disease, schistosomiasis, have potential interest in terms of follow-up of morbidity in these parasitic diseases.

KEY WORDS : lymphatic filariasis, fibrosis markers, eosinophil proteins, French Polynesia.

\section{INTRODUCTION}

T ymphatic filariasis (LF) presents a broad clinical spectrum, including acute (adenolymphangitis, $\mathrm{ADL}$ ) and chronic (mainly hydrocoele and disfiguring elephantiasis), triggered by adult worms of Wuchereria bancrofti in the lymphatics (Kumaraswami in Nutman, 2000). It is believed that, at least in part, the pathogenesis of LF (and other chronic helminth diseases) is related to a persistent immunological response of genetically susceptible person to relevant parasite antigens. Consequently, an extensive lymphodoema and deposition of fibrous material is seen in this chronic pathology, suggesting that connective tissue metabolism is modified during this long-term process. The search for an alternative to painful and sometimes

\footnotetext{
* Immunology \& ** Epidemiology Units, Institut de recherches médicales Malardé, Papeete 98713 Tahiti (French Polynesia); *** Pharmaceutic Faculty, Lyon, France; ***** Danish Bilharziasis Laboratory, Charlottenlund, Denmark; ${ }^{* * * * * * *}$ Institut de biologie et chimie des protéines, UMR 5086 CNRS-UCBL, Lyon, France.

Correspondence: Dr Philippe Esterre, Institut Pasteur de Guyane Française, 97306 Cayenne Cedex (French Guiana)

Tel.: 594594292612 - Fax: 594594318083

E-mail: pesterre@pasteur-cayenne.fr
}

Résumé : MARQueURS DE FIBROSE ET PROTÉINES DE L'ÉOSINOPHILE DANS LA FILARIOSE LYMPHATIQUE

Les dosages d'un certain nombre de marqueurs circulants de fibrose (collagène I, procollagène III, hyaluronane), déjà validés sur plusieurs fibroses d'origine parasitaire, et de protéines des granules de l'éosinophile (protéines ECP et EPX), impliquées dans l'immunité anti-larves, ont été réalisés chez des patients polynésiens présentant différents stades de filariose lymphatique (adénolymphangite aigue, chylurie, hydrocèle, éléphantiasis). Ces résultats ont été comparés avec ceux observés dans une lymphangite microbienne cliniquement très proche (érysipèle) et des contrôles endémiques. Deux marqueurs potentiels de morbidité, déjà validés en matière de bilharziose, ont été identifiés : le hyaluronane sérique et la protéine ECP; le premier de manière significative aussi bien dans les lymphangites aiguës que dans les éléphantiasis chroniques.

MOTS CLÉS : filariose lymphatique, marqueurs de fibrose, protéines de l'éosinophile, Polynésie Française.

hazardous, at least for the liver, biopsy has led to the development of serological and urinary markers of disease activity reflecting the turn-over of extracellular matrix (ECM). This non-invasive follow-up of fibrosis has been applied in parasitology, mainly in schistosomiasis-associated liver fibrosis (Secor et al., 1994; Ricard-Blum et al., 1998) chromoblastomycosis - (RicardBlum et al., 1998) and lymphatic - (Fleming-Hubert et al., 1997) associated elephantiasis.

We also measured the serum and urine levels of two eosinophil granule proteins supposed to reflect both the release of toxic cationic enzymes able to damage the larval forms and the eosinophil-rich inflammation against the tissue-dwelling helminth parasites. Eosinophil cationic protein (ECP) and the neurotoxin eosinophil peroxidase (EPX) are major constitutent of secondary granules which usually correlate with peripheral eosinophil counts, even if the circulating pool is only a minor part of the global eosinophil population. Serum levels of ECP and EPX have been measured in patients with LF-associated elephantiasis and schistosomiasis mansoni (Tischendorf et al., 1996). In addition urinary levels of ECP are significantly correlated with intensity of infection and ultrasonographically detectable urinary tract pathology in schistosomiasis 
haematobium (Leutscher et al., 2000, Reimert et al., 2000).

In the present study, we measured the concentration of serum markers of fibrosis (type I collagen, N-terminal propeptide of type III collagen (PIIIP)) and glycosaminoglycan hyaluronan (HA), first to investigate their relationship with the clinical status of the patients and then to determine if they are useful to monitor the effect of specific treatment. Furthermore, a previous analysis of circulating adhesion (soluble ICAM-1, VCAM1 and various selectins) and angiogenic (VEGF and endothelin) molecules (Esterre et al., 2005) provided us the possibility to investigate the relationship beetween these immunological markers and ECM metabolites or inflammatory markers (ECP, EPX). The main objective of these investigations is to delineate more precisely the immunopathological response underlying the pathogenesis of lymphatic filariasis, including the granuloma-associated fibrosis.

\section{PATIENT AND METHODS}

\section{PATIENTS}

T The 30 individuals included in this study were residents of the Society Archipelago, French Polynesia, a long-term identified area of LF transmission under incomplete control (Esterre et al., 2001), consulting a specialized clinic within the Malardé Institute, Papeete, French Polynesia. Prevalence (expressed as a percentage) and intensity (expressed as a geometric mean number of microfilaria (Mf) per milliliter of blood) of infection were performed by standardized methods, as the ELISA-based detection of filaria-specific IgG and circulating antigens. After confirmation of clinical LF and morbidity staging (WHO, 1992, Freedman et al., 1998), all patients (17 with acute fila- rial ADL, seven chronic elephantiasis, four hydrocoele and two chyluria) were subsequently treated with diethyl carbamazine (DEC).

The patients were compared to four bacterial ADL (typical erysipela closely mimicking filarial ADL, see Esterre et al., 2000) and 22 endemic controls, i.e. lifelong residents, of Maori or European origin, of the archipelago who had neither a positive parasitological nor immunological result. The description of these two groups is presented in Table I.

\section{BLOOD AND URINE SAMPLING}

Informed consent was obtained prior to collection of blood or urine by the medical team. Blood sampling was organized by venepuncture and serum was obtained by centrifugation. Aliquots of serum and urine were immediately frozen at $-20^{\circ} \mathrm{C}$ for subsequent laboratory analysis.

\section{EXTRACELLULAR MATRIX METABOLITES}

The urinary concentration of the type I collagen was measured by an ELISA test (CrossLapsH ${ }^{\mathrm{TM}}$, Nordic Bioscience, Herlev, Denmark) specific for a 8-amino acid sequence found in the C-telopeptide of the a chain of type I collagen (Bonde et al., 1994). The molecules measured in this assay are derived from degradation of collagen I and not from newly synthesized collagen type I. The reference range in healthy adults was 80 $330 \mu \mathrm{g} / \mathrm{mmol}$ creatinin, urinary creatinine being measured by the Jaffé procedure (Sigma Diagnostics, St-Louis, MO). PIIIP is released in the circulation during the synthesis of type III collagen via lymphatic vessels. PIIIP was analyzed by radioimmunoassay (PIIIP RIAgnost4, Schering lab, Gif-sur-Yvette, France) and varied between 0.3 and $0.8 \mathrm{U} / \mathrm{mL}$ in healthy controls. Circulating HA, a marker of connective tissue destruction, was measured in the serum by high-affinity radiometric

\begin{tabular}{|c|c|c|c|c|c|}
\hline $\begin{array}{l}\text { Endemic controls } \\
\text { \& patients groups }\end{array}$ & No. & $\begin{array}{l}\text { Age }(\text { mean } \pm S D) \\
\text { in years }\end{array}$ & $\begin{array}{c}\text { Sex } \\
\text { (no. of males/ } \\
\text { no. of females) }\end{array}$ & Inclusion criteria & Immunologic criteria \\
\hline Endemic controls & 22 & $29.9 \pm 13.2$ & $13 / 9$ & $\begin{array}{l}\text { Resident, MF = } 0 \text {, } \\
\text { No disease }\end{array}$ & IgG-CA- \\
\hline \multicolumn{6}{|l|}{ Patients } \\
\hline FilL group & 17 & $48.7 \pm 18.3$ & $8 / 9$ & $\mathrm{ADL}, \mathrm{Mf}+$ & $\operatorname{IgG}+\mathrm{CA}+$ \\
\hline EleP group & 7 & $38.2 \pm 9.8$ & $4 / 3$ & Typical elephantiasis & $\operatorname{IgG}+\mathrm{CA} \pm$ \\
\hline Hyd group & 4 & $33.4 \pm 10.9$ & $2 / 2$ & Hydrocele & $\operatorname{IgG}+\mathrm{CA} \pm$ \\
\hline ChyL group & 2 & ND & $1 / 1$ & Chyluria & $\operatorname{IgG}+\mathrm{CA} \pm$ \\
\hline Microbial lymphangitis & 4 & ND & $2 / 2$ & $\begin{array}{l}\text { Typical erysipela, } \\
\mathrm{MF}=0\end{array}$ & $\begin{array}{l}\text { IgG-CA- } \\
\text { ASLO +ASDB + }\end{array}$ \\
\hline
\end{tabular}

IgG: ELISA-based identification of anti-Brugia malayi antigen specific antibodies; CA: circulating antigens identified by immunochromatography (ICT test) and controlled by Og4c3 ELISA; MF: microfilaremia detected by membrane filtration; ADL: acute adenolymphangitis; ASLO: anti-streptolysin O antibodies; ASDB: anti-streptodornase B antibodies; ND: not done. Results are expressed as mean values \pm standard deviations.

Table I. - Clinical patients and endemic controls included in the fibrosis study. 
assay (HA test, Pharmacia Diagnostics, Les Ulis, France) and reference interval was 7-90 $\mu \mathrm{g} /$ Lin healthy adults.

\section{SERUM AND URINE ECP AND EXP}

Eosinophil granule proteins were measured by a polyclonal sandwich type ELISA as previously described (Reimert et al., 1991a, 1991b), with serum reference ranges of $0.3-51.4 \mathrm{ng} / \mathrm{mL}$ and $8-38.5 \mathrm{ng} / \mathrm{mL}$ for ECP and EPX, respectively (Leutscher et al., 2000; Tischendorf et al., 1996). For urine samples, the refence ranges were $0.2-678 \mathrm{ng} / \mathrm{mL}$ and $70-1800 \mathrm{ng} / \mathrm{mL}$ for ECP and EPX, respectively (Leutscher et al., 2000; Reimert et al., 1993).

\section{STATISTICAL ANALYSIS}

Data are presented as mean \pm SD. Statistical significance of between groups difference was assessed by the nonparametric Mann-Whitney $U$-test. The relationship between two parameters was assessed by Spearman rank correlation coefficient. As usual, the significance level was defined as $P<0.05$ and the statistical analysis performed with dedicated softwares (Statmed, Medical computer lab., Faculty of Medicine, Nancy, France and StartViewII, Abacus Concepts, Berkeley, CA). In addition, the potential relationship between circulating ECM metabolites or eosinophil markers and adhesion molecules (Esterre et al., 2005) was investigated in parallel.

\section{RESULTS}

\section{CIRCULATING FIBROSIS MARKERS IN ENDEMIC CONTROLS}

M ean circulating concentrations of the different fibrosis markers were in the normal range for the 22 endemic controls: $250.1 \pm 148.8 \mu \mathrm{g} / \mathrm{L}$, $0.95 \pm 0.21 \mathrm{U} / \mathrm{mL}$ and $20.1 \pm 12.1 \mu \mathrm{g} / \mathrm{mL}$ for collagen I, PIIIP and HA, respectively.

\section{CIRCULATING FIBROSIS MARKERS IN FILARIASIS PATIENTS}

We did not observe any correlation between fibrosis markers levels and the infection status (low vs high parasitemia).

Collagen I urine levels in filarial $(146.8 \pm 74.1 \mathrm{ng} / \mathrm{mL})$ and microbial lymphangitis $(118.9 \pm 69.2 \mathrm{ng} / \mathrm{mL})$ patients were significantly decreased $(t=4.05, P=0.0076$ and $t=2.43, P=0.022$, respectively) by comparison with controls. The levels observed with chyluria (165.8 \pm $24.2 \mathrm{ng} / \mathrm{mL})$, hydrocoeles $(181.8 \pm 132.9 \mathrm{ng} / \mathrm{mL})$ and elephantiasis $(153.8 \pm 20.8 \mathrm{ng} / \mathrm{mL})$ were not significantly different from the control values (Fig. 1). Surprisingly, the PIIIP values were significantly lower $(t=12.32, P<$ $0.001)$ for the hydrocoeles group $(0.60 \pm 0.5 \mathrm{U} / \mathrm{mL})$ than in the controls $(0.95 \pm 0.21 \mathrm{U} / \mathrm{mL})$, the microbial $(1.10 \pm$

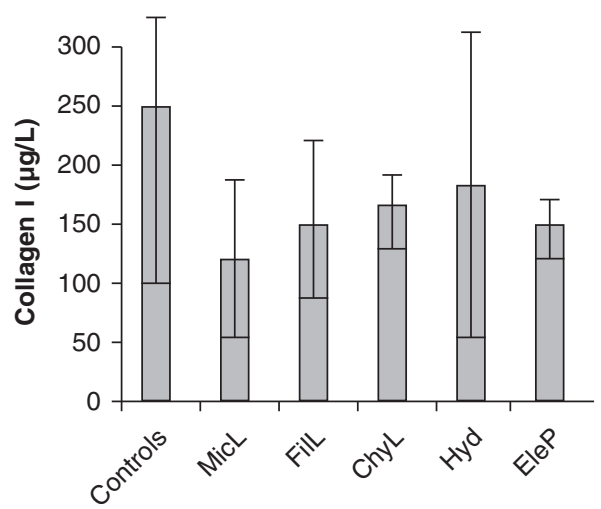

Fig. 1. - Collagen I levels, as determined by ELISA, in urine of patients with lymphatic filariasis according to their clinical status. FilL: filarial lymphangitis; ChyL: chyluria; Hyd: hydrocoele; EleP: elephantiasis, in comparison with controls and bacterial lymphangitis (MicL).

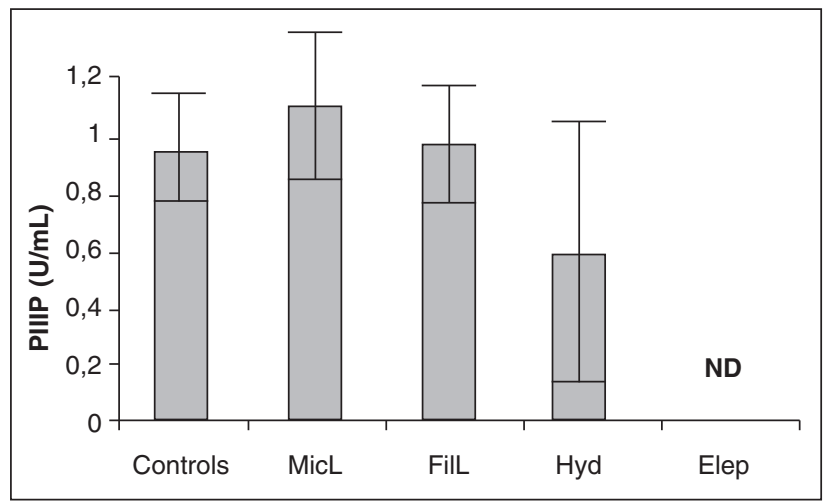

Fig. 2. - Serum levels of N-terminal propeptide of type III collagen, determined by RIA, in patients with lymphatic filariasis according to their clinical status.

FilL: filarial lymphangitis; ChyL: chyluria; Hyd: hydrocoele; EleP: elephantiasis, in comparison with controls and bacterial lymphangitis (MicL).

$0.3 \mathrm{U} / \mathrm{mL})$ and the filarial $(0.97 \pm 0.22 \mathrm{U} / \mathrm{mL})$ lymphangitis patients (Fig. 2). Unfortunately, elephantiasis samples were not available for this analysis. More interestingly, the HA values (Fig. 3) were significantly increased with the microbial $(104.5 \pm 92.1 \mu \mathrm{g} / \mathrm{mL})$ and filarial $(65.1 \pm$ $36.0 \mu \mathrm{g} / \mathrm{mL}$ ) lymphangitis groups by comparison with the controls $(t=3.94, P=0.006$ and $t=5.37, P<0.001$, respectively). The same significant increase $(t=6.77$, $P<0.001)$ is observed with the elephantiasis group $(139.1 \pm 52.8 \mu \mathrm{g} / \mathrm{mL})$, although the levels observed in the hydrocoeles were not different from the control values (Fig. 3). As expected, it is interesting to note that the 'elephantiasis' levels were significantly increased by comparison with the 'filarial lymphangitis' and 'hydrocoeles' levels $(t=3.42, P=0.003$ and $t=3.58, P=0.009$, respectively). 


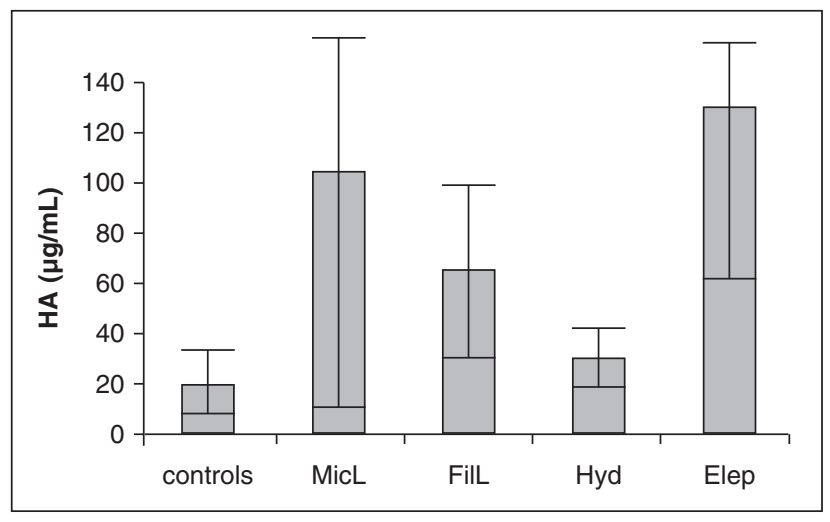

Fig. 3. - Serum levels of hyaluronan (HA), determined by radiometry, in patients with lymphatic filariasis according to their clinical status. FilL: filarial lymphangitis; ChyL: chyluria; Hyd: hydrocoele; EleP: elephantiasis, in comparison with controls and bacterial lymphangitis (MicL).

As observed on urine taken during a follow-up of seven patients, the levels of collagen I slightly decrease (from $146.2 \pm 91.4 \mu \mathrm{g} / \mathrm{L}$ to $133.9 \pm 54.0 \mu \mathrm{g} / \mathrm{L}$ ) six months after treatment with DEC (data not shown). Unfortunately the sampling was incomplete $(n<5)$ for PIIIP and HA.

\section{ECP AND EXP IN CONTROLS}

Mean serum concentrations of the two eosinophil molecules were in the normal range for the 22 endemic controls $(32.2 \pm 29.1 \mathrm{ng} / \mathrm{ml}$ and $30.5 \pm 5.5 \mathrm{ng} / \mathrm{mL}$, for ECP and EPX respectively). The urine levels were not measured in the control group. A positive $(r=0.958)$ and highly significant correlation ( $\mathrm{n}=22, P<0.001$ ), was observed between serum, but not urine, levels of ECP and eosinophilia $(\mathrm{Y}=-0.06+0.084 \mathrm{X})$ calculated in the haematology laboratory.

\section{ECP AND EPX IN FILARIASIS PATIENTS}

We did not observe any correlation between eosinophil molecules levels and the infection status (low $v$ high parasitemia). The serum levels for ECP (Fig. 4) and EPX for the acute filarial lymphangitis $(42.9 \pm 29.1 \mathrm{ng} / \mathrm{mL}$ and $33.3 \pm 7.4 \mathrm{ng} / \mathrm{mL}$, respectively), chyluria $(6.6 \pm$ $0.7 \mathrm{ng} / \mathrm{mL}$ and $40.1 \pm 14.5 \mathrm{ng} / \mathrm{mL}$, respectively), hydrocoele $(23.6 \pm 24.4 \mathrm{ng} / \mathrm{mL}$ and $28.3 \pm 20.0 \mathrm{ng} / \mathrm{mL}$, respectively) patients were not significantly different from the controls and microbial lymphangitis patients. The only interesting trends, although of borderline statistical significance, were observed with elephantiasis patients who had increased serum ECP levels $(96.8 \pm 88.2 \mathrm{ng} /$ $\mathrm{mL}$ ) by comparison with hydrocoele patients (see Fig. $4, t=1.97, P=0.070)$ and controls $(t=1.94, P=$ 0.071 ).

Urine ECP levels were were slightly increased compared to normal values (as urine concentrations should

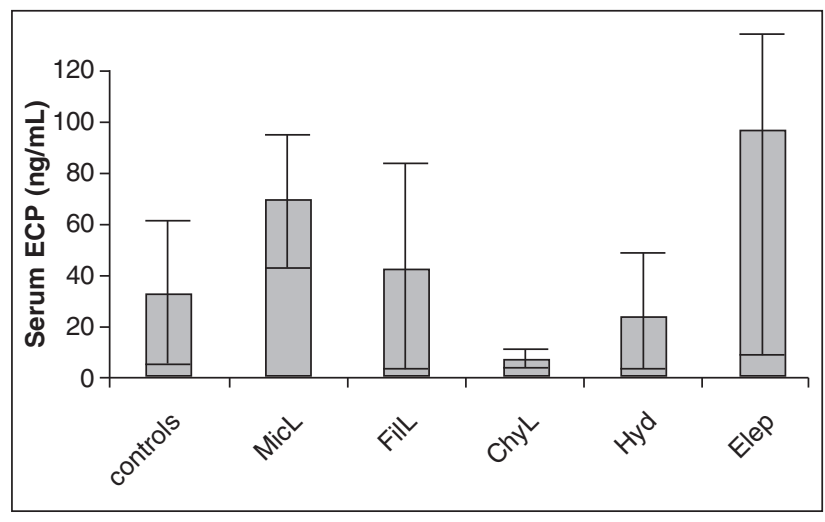

Fig. 4. - Eosinophil Cationic Protein (ECP) levels, determined by ELISA, in sera of patients with lymphatic filariasis according to their clinical status.

FilL: filarial lymphangitis; ChyL: chyluria; Hyd: hydrocoele; EleP: elephantiasis, in comparison with controls and bacterial lymphangitis (MicL).

be below 5 ng: see Reimert et al., 2000) for filarial lymphangitis $(3.2 \pm 5.6 \mathrm{ng} / \mathrm{mL})$, chyluria $(9.7 \pm 8.3 \mathrm{ng} / \mathrm{mL})$, hydrocoeles $(3.3 \pm 1.1 \mathrm{ng} / \mathrm{mL})$ and elephantiasis $(1.75 \pm$ $1.5 \mathrm{ng} / \mathrm{mL}$ ). Its interesting to note that the microbial lymphangitis patients had also a normal level of serum $\operatorname{ECP}(69.9 \pm 28.1 \mathrm{ng} / \mathrm{mL})$. Urine EPX levels were within the normal range for chyluria $(731.3 \pm 238.9 \mathrm{ng} / \mathrm{mL})$ and hydrocoeles $(861.4 \pm 337.1 \mathrm{ng} / \mathrm{mL})$, and slightly increased in filarial lymphangitis $(2169 \pm 383.3 \mathrm{ng} / \mathrm{mL})$ and elephantiasis $(2075 \pm 1181.5 \mathrm{ng} / \mathrm{mL})$ patients.

\section{RELATIONSHIP BETWEEN LEVELS OF SOLUBLE MOLECULES}

It seems appropriate to use regression analyses in order to compare the levels of the different fibrosis and eosinophil-associated proteins as previously done for adhesion proteins (Esterre et al., 1998, 2005). No relationship was found between serum PIIIP and urine collagen I levels. A positive relationship was observed between serum PIIIP and HA levels $(r=0.46, P=0.0027, \mathrm{Y}=-82.5+$ $125.0 \mathrm{X})$ on 23 patients. More interestingly, there was a negative correlation $(P<0.001)$ between urine collagen I and serum HA levels $(r=-0.499, \mathrm{Y}=213.2-0.9 \mathrm{X})$ observed on 41 couples. No relationship was found between serum and urine levels of ECP and EPX.

\section{ASSOCIATION BETWEEN FIBROSIS-}

AND EOSINOPHIL-ASSOCIATED PROTEINS

AND THE OTHER POTENTIAL MORBIDITY MARKERS

Correlations between levels of fibrosis- or eosinophilassociated proteins and other biochemical markers (adhesion and angiogenic factors) have been actively sought but did not revealed any significant result. A trend, although not statistically significant in our sample $(r=-0.22, \mathrm{n}=42, P=0.163)$, was noticed between 
ECP and VEGF levels (Esterre et al., 2005). The same was true $(r=0.23, \mathrm{n}=36, P=0.169)$ between ECP and HA levels.

\section{DISCUSSION}

This is, to the best of our knowledge, one of the few study comparing eosinophil-related (Tischendorf et al., 1996) and ECM markers (Fleming-Hubertz et al., 1997) with parasitological and clinical status in LF. Serum HA was considered as a potentiel marker of schistosomiasisassociated morbidity, as precisely quantified by ultrasonography (Ricard-Blum et al., 1999), and was well-correlated with the best immunological marker (sICAM-1: Esterre et al., 1998). Interestingly, the circulating levels were significantly increased in elephantiasis and ADL patients but also, at a lower level of significance, in microbial lymphangitis patients. Up to $90 \%$ of HA is degradated through the lymphatics (Fraser et al., 1998), increased serum levels likely reflect tissue damage around the lymphatics harbouring the adult worms. It might constitute a potential marker of morbidity in this pathology, as previously indicated in a pionnering study in Tanzania (Fleming-Hubertz et al., 1997). An intriguing finding was that significant correlations were found beetween serum HA level and urine level of collagen I (negative correlation) or serum level of PIIIP (positive correlation). Serum PIIIP levels were significantly decreased in hydroceles but, unfortunately, not tested on elephantiasis patients. Urine collagen I levels were significantly decreased in ADL and microbial lymphangitis patients. The increase of serum, but not urine, ECP levels was at the limit of significance probably due to a limited sample.

Another potential morbidity marker is serum ECP. Indeed we observed an increase, unfortunately at the limit of significance probably due to a limited sample, of serum but not urine ECP levels in elephantiasis. This trend, also observed in African elephantiasis patients (Tischendorf et al., 1996), indicated a different pathogenetic mechanism for this chronic form of the disease (Freeman, 1998; Kumaraswami, 2000). However the precise pathogenesis of lymphatic disease in filariasisendemic areas is not fully elucidated, particularly in long-standing mass chemoprophylaxis areas such Polynesia, the single exception being likely streptococcalassociated acute lymphangitis (Esterre et al., 2000). Correlations between levels of fibrosis or eosinophilassociated proteins and other biochemical markers (adhesion and angiogenic factors), studied in the companion paper (Esterre et al., 2005), did not revealed any significant result confirming that the granulomatous and fibrosis processes are independantly regulated.

\section{REFERENCES}

Bonde M., Qvist P., Fledelius C., RiIs B.J. \& Christiansen C. Immunoassay for quantifying type I collagen degradation products in urine evaluated. Clinical Chemistry, 1994, 40, 2022-2025.

Esterre P., Plichart C., Huin-Blondey M.O. \& Nguyen L.N. Role of streptococcal infection in the acute pathology of lymphatic filariasis. Parasite, 2000, 7, 91-94.

Esterre P., Plichart C., Sechan Y. \& NGuyen N.L. The impact of 34 years of massive DEC chemotherapy on Wuchereria bancrofti infection and transmission: the Maupiti cohort. Tropical Medicine and International Health, 2001, 6, 190195.

Esterre P., Raobelison A., Ramarokoto C.E., Ravaoalimalala V.E., BOISIER P. \& Roux J. Serum concentrations of sICAM1, sE-, sP-, sL-selectins in patients with Schistosoma mansoni infection and association with disease severity. Parasite Immunology, 1998, 20, 369-376.

Esterre P., Plichart C., Huin-Blondey M.O. \& Nguyen L.N. Soluble cellular adhesion molecules, selectins, VEGF and endothelin-1 in patients with Wuchereria bancrofti infection and association with clinical status. Parasite Immunology, 2005, 27, 9-16.

FreEDMAN D.O. Immune dynamics in the pathogenesis of Human lymphatic filariasis. Parasitology Today, 1998, 14 , 229-234.

Fraser J.R., LAURENT T.C., Kimpton N.G., CAHILl R.N. \& VAKAKIS N. Uptake and degradation of hyaluronan in lymphatic tissue. Biochemistry Journal, 1998, 256, 153-158.

Fleming-Hubertz S., Simonsen P.E., Jensen L.T. Circulating connective tissue metabolites in patients with bancroftian filariasis. Transactions of the Royal Society of Tropical Medicine and Hygiene, 1997, 91, 442-445.

Leutscher P.D.C., Reimert C.M., Vennervald B.J., RavaOAlimalala V.E., Ramarokoto C.E., Serieye J., Raobelison A., Rasendramino M., Christensen N.O. \& Esterre P. Morbidity assessment in urinary schistosomiasis infection through ultrasonography and measurement of ECP in urine. Tropical Medicine and International Health, 2000, $2,88-93$

Reimert C.M., Venge P., Kharazmi A. \& Bendtzen K. Detection of eosinofil cationic protein by enzyme linked immunosorbent assay. Journal of Immunological Methods, 1991a, 138, 285-290.

Reimert C.M., Minuva U., Kharazmi A. \& Bendtzen K. Eosinofil protein X/eosinofil derived neurotoxin: Detection by enzyme linked immunosorbent assay and purification from normal human urine. Journal of Immunological Methods, 1991b, 141, 97-104.

Reimert C.M., Ouma J.H., Mwanje M.T., Magak P., Poulsen L.K., Vennervald B.J., Christensen N.O., Kharazmi A. \& BendtZEN K. Indirect assessment of eosinophiluria using ECP and EPX. Acta Tropica, 1993, 54, 1-12.

Reimert C.M., Mshinda H.M., Hatz C.F., Kombe Y., Nkulila T., Poulsen L.K., Christensen N.Ø. \& Vennervald B.J. Quantitative assessment of eosinophiluria in Schistosoma haematobium infections: A new marker of infection and bladder 
morbidity. American Journal of Tropical Medicine and Hygiene, 2000, 62, 19-28.

Ricard-Blum S., Hratmann D.J., Grenard P., Ravaoalimalala V.E., Boisier P. \& Esterre P. Relationships between several markers of extracellular matrix turn-over and ultrasonography in human schistosomiasis mansoni. American Journal of Tropical Medicine and Hygiene, 1999, 60, 658-664.

Secor W.E., Reis M.D., Ramos E.A.G., Matos E.P., Reis E.A., CARMOT.M.A. \& HARn D.A. Soluble intercellular adhesion molecules in human schistosomiasis: correlations with disease severity and decreased responsiveness to egg antigens. Infection Immunity, 1994, 62, 2695-2701.

Tischendorf F.W., Brattig N.W., Buttner D.W., Pieper A. \& LiNTZEL M. Serum levels of ECP, EDN and MPO in infections with filariae and schistosomes. Acta Tropica, 1996, 62, 171-182.

World Health Organisation. Lymphatic filariasis, $5^{\text {th }}$ report of WHO experts committee. Technical Report 821, WHO Ed., Geneva, 1992.

Reçu le 24 octobre 2005 Accepté le 7 mars 2006 